Int.J. Hum. Soc. Dev. Res.

ISSN (P):2521-1439; ISSN (E):2523-4331

Volume 2, № 2, 2018. 29-38

DOI: $10.30546 / 2523-4331.2018 .2 .2 .29$

\title{
An examination of the effect of Police department Personnel's Stress and Burnout levels on their Agencies \\ (A qualitative research)
}

\section{Tahsin FIDAN}

Institute of Management Business and Law, Russia

(C) The Author(s) 2018

\begin{abstract}
This research which was conducted with the qualitative research technique utilized data collection instruments of observation, face-to-face interview and document analysis. The research sample was composed of 110 randomly selected police department personnel (23 members of administration class, 87 police officers) serving in various units in İstanbul. The interview forms used in the research was prepared by the researcher based on the opinions of the thesis supervisor and the department lecturers. Reliability of the interview form was ensured with an application with a 10-individual group. 6 questions were asked to the participant to collect different data. The participant police force members were visited and informed of the research purpose and content. The answers to the questions were noted down one by one.

It was concluded in the research that almost all of the participants started their careers willingly but feel professional apathy due to unjust practices and problems which they experience or witness in the profession. It was found that the reasons are generally unjust occupational practices, unmerited changes of place, irregularity of working hours, inadequate wage and attitudes and behaviors of superior ranks towards subordinates.

C2018.All rights reserved.
\end{abstract}

\section{ARTICLE HISTORY}

Received: $18 / 02 / 2018$

Accepted: 19/8/2018

Published online: 05/10/2018

\section{KEYWORDS}

Police force, perceived stress, burnout, agency 


\section{Introduction}

Policing is one of the most stressful professions in Turkey. It is a known fact that all ranked or unranked members of police force who fight against crime and criminals with the responsibility attributed by the law to them are subjected to much stress than employees of other occupational groups either in their working environment or in their domestic life. In this era, the delivery of the tasks assigned to its members is not alone sufficient for the organization of law enforcement which aims success in all areas. The organization now requires skillful personnel who investigate, learn and realize what they have learned differently from the simple act of delivering the assigned task. However, political interventions with the organization and forced labor and unbalanced working conditions of police force members in the force deteriorate the normalization of daily working hours, which causes them to be affected negatively and lead to stress overload.

Coping with stress starts with resistance of organism to stress. When there is no resistance and a way to eliminate the source of stress cannot be found, health problems occur. Problems that cannot be solved for a long time may leave permanent and harmful impacts on body. These problems may include mental and emotional disorders such as sleep disorders, stroke, frequent mistakes and accidents, recklessness, lack of concentration, introversion, extreme anxiety, worry, extreme indifference, negligence, alcohol overuse, difficulty in establishing relationships, forgetfulness, and depression (Baltaş, 2002, p. 26-27).

Internal conflict in the profession and the stress coming from such conflict make employees inclined to have burnout. Elongated stimulation in individual leads to burnout. Burnout is also related to employee's success at coping with stress. Burnout causes individuals to feel hopeless and worn-out; so, it refers to a condition that is much more negative than stress (Eroğlu, 2006).

A police force member who staggers under stress and burnout will find it hard to deliver his/her actual duty, not being able to focus on his/her job. This will also have a negative impact on the police's agency. According to Weber, it is very important to understand the causes of anything, and understanding anything precedes exploring them (Demirel, 2013, p.3621-369). Hence, desire to take action is constituted by a process which features the logical aspect including understanding and thinking. 7

Theories of sociology take the social structure into account as they address individual's agency. Weber argues that humans take action in consideration of both their subjective experiences and others' experiences. 
This is what makes the action social. Furthermore, the action is social because it is guided and involves subjective meaning with an eye towards behaviors of others (Wallece \& Wolf, 2012).

The stress experienced by police officials at several stages of the working life burns them out over time and causes them to perform poorly. For police force members to have a peaceful working environment today, it has become a necessity to minimize the stress experienced by them and find preventive options to reduce the emotional tension. Stress as the greatest hindrance of agency is a problem that should be identified at the beginning stage and fought with. The findings achieved in this study are important to decreasing the stress factors of the police.

\section{Methodology}

The sample of this study using the qualitative model was composed of 110 randomly selected police force members ( 23 members of administration class and 87 police officers) of several ranks serving in İstanbul Police Department.

\section{Data collection instruments}

The research data were collected with interview forms and the observation technique. The interview forms used in the research was prepared by the researcher based on the opinions of the thesis supervisor and the department lecturers. Reliability of the interview form was ensured with an application with a 10 -individual group. 6 questions were asked to the participants in the interview form. The questions were designed to collect diverse data. The participant police force members were visited and informed of the research purpose and content. Themes were created out of the most emphasized topics in the answers of the participants.

\section{Findings and Discussion}

The qualitative sample of the research was composed of 110 randomly selected police force members ( 23 members of administration class, 87 police officers) serving in various units in İstanbul. To this end, it is sought for answer to the following questions:

Research Question 1: What are the problems that you experience in your professional life and how do these problems affect your stress level? 
Table 1. Participant opinions on the problems that they experience in their professional lives and their effects on the stress level

\begin{tabular}{lcc}
\hline Theme & F (n = 110) & \% \\
\hline Unjust practices cause problems. & 79 & 71.8 \\
\hline Long working hours cause problems. & 85 & 77.2 \\
\hline Inadequate wage causes problems. & 75 & 68.1 \\
\hline
\end{tabular}

The answers given by the participants to this question were grouped in the topics of unjust practices in the organization, long working hours and inadequate wage. Table 1 shows that $77.2 \%$ of the participants agree on long working hours.

a) Working Hours: The topics which the participants complained about the most are irregularity of working hours and multitude of additional duties. The 12-12 working system sometimes continue for months. Stating that this has a negative impact on their families and social circles, the participations reported that they experience extreme stress and became alienated from the profession. One of the participants expressed his/her distress as follows:

"We mostly work according to the 12-12-hour system. We do not have a special time we can spare for ourselves or our families. At a moment of resting, we are suddenly called for duty. This multiplies the existing stress by two. My sense of agency is about this. I must provide for my family although the job ruined my life" (Participant: Police Officer [76]).

b) Unjust Practices: One of the problems which cause the participants to have higher stress levels the most is the presence of unjust professional practices. An interviewed police administrator reported as follows:

"I cannot even see my children's faces. They are already asleep when I am home; we cannot run into each other as I leave early in the morning. They are growing up without me there. The work density and insufficient personnel in the unity increase the workload on each employee. On the top of it, when we respond to a case, a representative of party $X$ calls and try to distract it toward a different aspect, which maximizes the tension I am inside. I am not happy with my job like I used to." (Participant: Commissioner of Police [1]).

The findings achieved in İlgen's (2017) “Effect of Police Motivation on Police-Public Affairs: the Case of Malatya-Doganyol" about the negative effects of unjust practices, imbalance of working hours and inadequate wage on police force members' stress and motivation coincide with the findings of this research. 
c) Wage: The participants complained about inadequate monthly wages and low overtime pays for additional duties. Statements of a participant who serves in the administrative staff are remarkable.

"It is forbidden to borrow money from subordinates in the police disciplinary code; we cannot tell our superiors about our problem. Besides, they would kick us out of their rooms if we told we had financial problems. We cannot borrow from the shopkeepers, from our colleagues. Our wage comes up short. We owe to banks to get by. We keep making calculations by the end of each month. This causes us to be more aggressive both at work and in our family life. On pay days, I stagger under stress instead of being happy" (Participant: Superintendent Class (21).

Çam and Çakır (2008) emphasize the fact that "members of police force and justice should not worry about livelihood to prevent crime and ensure that criminals are arrested and punished properly." The participants stated that they cannot receive overtime pay although they deliver more duties than required by the nature of their jobs and due to additional duties and reported that this affect their commitment negatively and cause them to be more aggressive.

Research Question 2: How does your environment of duty affect your stress and burnout level?

Table 2. Participant opinions on the effect of duty environments on their stress and burnout levels

\begin{tabular}{lcc}
\hline Theme & F (n=110) & \% \\
\hline $\begin{array}{l}\text { Working environment affects police force members' stress } \\
\text { and burnout levels. }\end{array}$ & 86 & 78.1 \\
\hline $\begin{array}{l}\text { Participants' levels of trust in their colleagues affect their } \\
\text { stress and burnout levels. }\end{array}$ & 75 & 68.1 \\
\hline $\begin{array}{l}\text { Family life affected by work problems affect their stress } \\
\text { and burnout levels. }\end{array}$ & 83 & 75.4 \\
\hline $\begin{array}{l}\text { Dreams about future and planning affect their stress and } \\
\text { burnout levels. }\end{array}$ & 80 & 72.7 \\
\hline
\end{tabular}

$78.1 \%$ of the answers given by the participants to the question "How does your environment of duty affect your stress and burnout level?" were found to be grouped in the theme "Working environment affects police force members' stress and burnout levels".

It was observed that the participants above average do not trust their colleagues and cannot take long-term decisions for their future. The police force members under high levels of stress reflect the trouble they have at work to their 
families, which lead both their professional life and family life to adversity. Workrelated stress continuing in the family life drags them into burnout syndrome. This is an important issue as it causes them to perform poorly and make mistakes in tasks that require attention.

Policing is among occupational groups which require being in constant relation with society and have a high level of trust. Recognition of the profession within society depends on that the police can assure the society and cooperation with the public. Policing today in real terms is not just measured by the success at catching the criminals but also the quality of relations with the public (Karatepe, 2004, p. 269).

The police are one of the highly stressful occupational groups due to negative working conditions such as long, irregular working, the hierarchic structure and security concerns. About 12 hours of long working hours cause stress and depression which danger the health of police officers, and they are influenced by the harms of stress even further (Buker and Wiecko, 2007, p.291-309).

Research Question 3: How does your stress and burnout affect your agency?

Table 3. Participant opinions on the effects of their stress and burnout on their agency levels

\begin{tabular}{lcc}
\hline Theme & F (n=110) & \% \\
\hline Rise and falls in stress and burnout levels affect agency. & 64 & 58.1 \\
\hline Additional duties more than normal affect agency levels. & 77 & 70.0 \\
\hline $\begin{array}{l}\text { Incline and decline in spirits and motivation affect agency } \\
\text { levels. }\end{array}$ & 80 & 72.7 \\
\hline
\end{tabular}

$72.2 \%$ of the answers given by the police officers to the research question " How does your stress and burnout affect your agency?" were in the same opinion that high motivation increases their agency and low motivation decreases their agency.

The police force members perceive much stress by the nature of their jobs. The fact that the police have dangerous duties, extreme workload, irregular working hours, hierarchic and disciplinary factors have a negative impact on the physiology and psychology of the police. Incidents, problematic individuals they encounter everyday cause stress, and uncontrolled stress makes them perform low agency. Besides the personal traits, stress by the nature of job manifests itself with anger (Certel, 2012, p.161-162). 
Research Question 4: How do your stress and burnout levels affect your relations with society?

Table 4. Participant opinions on the effects of their stress and burnout levels on their relations with society

\begin{tabular}{lcc}
\hline Theme & $\mathbf{F ~ ( n = 1 1 0 )}$ & \% \\
\hline $\begin{array}{l}\text { Citizens' attitudes and behaviors toward the police } \\
\text { affect their stress and burnout levels. }\end{array}$ & 79 & 71.8 \\
\hline $\begin{array}{l}\text { Stress and burnout levels affect the police's attitudes } \\
\text { and behaviors toward citizens. }\end{array}$ & 85 & 77.2 \\
\hline
\end{tabular}

$77.2 \%$ of the answers given by the participants to the question "How do your stress and burnout levels affect your relations with society?" agreed on the opinion that stress and burnout levels affect the police's attitudes and behaviors toward citizens.

In the study titled "Importance of Public Relations in Policing and a Research on the Police's Perspective of Citizens: case of İstanbul" Çalışkan and Mencik (2016) emphasized that public relations should be further valued by police officials, they should attend to the personnel and approach them with care, plan the productivity and success in service without the disciplinary concerns and move away from prejudices the most. They concluded that the police force members who serve without the public support fail to prevent crime and ensure public peace (Çalışkan and Mencik, 2016; p.6). The result of the research in question coincides with the findings of our study.

Research Question 5: How do administrators' attitudes and behaviors in the organization affect your stress, burnout and agency levels?

\begin{tabular}{lcc}
\hline Theme & $\mathbf{F ~ ( n = 1 1 0 )}$ & $\mathbf{\%}$ \\
\hline $\begin{array}{l}\text { Administrators' attitudes and behaviors toward subordinates } \\
\text { affect personnel's stress and burnout levels. }\end{array}$ & 92 & 83.6 \\
\hline $\begin{array}{l}\text { Administrators' attitudes and behaviors toward subordinates } \\
\text { affect personnel's agency levels. }\end{array}$ & 76 & 69.0 \\
\hline $\begin{array}{l}\text { Weakness of police administrators in solving occupational } \\
\text { problems affects personnel's stress and agency levels. }\end{array}$ & 87 & 79.0 \\
\hline
\end{tabular}

$83.6 \%$ of the answers given by the participants to the question "How do administrators' attitudes and behaviors in the organization affect your stress, burnout and agency levels?" concentrated on the idea that administrators' attitudes and behaviors toward subordinates affect personnel's stress and burnout levels positively or negatively. 
"On a day when we were working in the 12-12-hour system, I went to my commissioner's office. There were citizens with him. I demanded a day-off, stating that my wife was sick. He did not let me although I do not take days off often. He virtually kicked me out of the room in front of the citizens. I continued my duty in low spirits. Therefore, I treated the citizens coming to me angrily. How could I benefit the citizen while I am prevented from providing my family with peace and trust?"

It is understood from this statement that administrator's attitude toward a subordinate who told that his wife was sick caused the subordinate to exhibit negative agency.

In a study investigating the perceived stress styles of police chiefs and officers, no difference was found between the perceived stress styles of both groups while it was observed that the police chiefs treated their subordinates less oppressively as the educational level increased (Perrot and Taylor, 1995, p.326$339)$.

Research Question 6: What do you think about taking support of psychologist or psychotherapy for coping with problems due to work environment?

\begin{tabular}{lccc}
\hline Theme & F (n=110) & \% \\
\hline $\begin{array}{l}\text { A police officer who receives psychological support } \\
\text { cannot stay in the profession; even so, he/she is assigned } \\
\text { to non-active service. }\end{array}$ & 90 & 81.8 \\
\hline It is necessary, but I cannot dare making such a demand. & 80 & 72.7 \\
\hline $\begin{array}{l}\text { Psychological disorder would be recorded in my } \\
\text { registration file and prevent me from making progress in } \\
\text { my career. }\end{array}$ & & 67.2 \\
\hline
\end{tabular}

$81.8 \%$ of the answers given by the participants to the question "What do you think about taking support of psychologist or psychotherapy for coping with problems due to work environment?" concentrated on the opinion that a police officer who receives psychological support cannot stay in the profession; even so, he/she is assigned to non-active service.

Receiving psychological support for coping with stress arising from their duties is one of the most important topics that should be addressed by the Turkish National Police Force for updating itself according to today's circumstances. Due to dire straits which the public have been in nowadays and education of poor quality, they somehow experience psychological disorders.

According to most of the participant police administrators and ranked and unranked police officers, "receiving psychological support" is just a phenomenon 
in theory in the police force. Moreover, it is a common assumption that consulting the organization for psychological disorder is a behavior that requires quitting the job. Providing police officers with psychological support so that they can cope with the stress they are subjected to under difficult circumstances need to be taken seriously. In several countries, psychological support for the police is based on legal obligation.

\section{Conclusion}

It was concluded in the interviews performed with the ranked and unranked police force members to collect qualitative data in the research that almost all of the participants started their careers willingly but feel professional apathy due to unjust practices and problems which they experience or witness in the profession. It was found that the reasons are generally unjust occupational practices, unmerited changes of place, irregularity of working hours, inadequate wage and attitudes and behaviors of superior ranks towards subordinates.

Administrators' attitudes and behaviors toward their subordinates in the police department which has a hierarchic and strict structure have an inevitably positive or negative impact on their performance. While fair administration keeps the personnel's spirits higher, an unjust and favoring style of administration cause their motivation to decrease, increasing the stress levels. It is truism that the police are obligated to serve for very long hours and subjected to extreme exhaustion and pressure. Extreme exhaustion prevents individuals from thinking logically, therefore causing them to behave wrongly and uncontrollably. It is of great importance to personnel's motivation that a police administrator achieves this fragile balance.Experiencing problems in several domains corporately and administratively, the police experience the depression of being doomed under the stress of their jobs. Majority of these problems has affected their agency levels negatively and made them get alienated from the profession. It can be argued according to the research that it is a critical necessity to reduce factors which lead to stress and burnout for the police.

\section{Disclosure statement}

No potential conflict of interest was reported by the author.

\section{Contact Information}

E-mail: abdullah.isiklar@btu.edu.tr 


\section{References and notes:}

Baltaş, A. and Baltaş, Z. (2002). Ways of Coping with Stress, Remzi Kitabevi. İstanbul

Buker, H. and Wiecko, F., (2007). Are causes of police stress global: Testing the effects of common police stressors on the Turkish National Police, Policing: An International Journal of Police Strategies and Management, 30, 2:291-309.

Certel Z., Bahadır Z. (2012). Examination of the Relationship between Self-Esteem, Trait Anger and Anger Expression Styles among Team Athletes, Selçuk University Journal of Physical Education and Sports Science, 2012; 14 (2): 157-164

Çalışkan, M. and Mencik, Y. (2016). Importance of Public Relations in Policing and a Research on the Police's Perspective of Citizens: case of İstanbul, KyrgyzTurkish Institute of Social Sciences, Economics and Entrepreneurship University, Jalalabad - Kyrgyzstan. Akademik Bakış Dergisi Issue: 60 March- April 2017

Çam, S., Çakır, İ. (2008). Comparison of Perceived Work-Related Stress among the Police by Certain Personal and Work-Related Variables, Polis Bilimleri Dergisi, 10 (3):21-40.

Demirel, D. (2013). Max Weber's Theory of Sociology. International Periodical For The Languages, 8 (12)361-369.

Eroğlu, F. (2006). Behavioral Sciences, Beta Yayıncılık, İstanbul

İlgen, N. (2017). Affect of Police Motivation on Police-Public Affairs: the Case of Malatya-Doğanyol, Postgraduate Thesis, Kahramanmaraş Sütçü İmam University, Department of Public Administration, Kahramanmaraş 2017:37

Kula, S. (2011). Occupational Stress And Work-Related Wellbeing Of Turkish National Police (Tnp) Members, PhD thesis, at the University of Central Florida Orlando, Florida,

Ozturk .H. (2018) A study on the life and leisure satisfaction Levels of offenders participating in the rapeutic recreational activities. International Journal of Humanities and Social Development Research. Vol 2 (1), 2018.Baku, Azerbaijan,74-85

Perrott, S. B. and Taylor, D. M., (1995). Attitudinal Differences Between Police Constables and Their Supervisors-Potential Influences Of Personality WorkEnvironment And Occupational Role. Criminal Justice and Behavior, 22, 326-339.

Wallece, R.A. and Wolf, A. (2012). Contemporary Sociological Theory. Ankara: Doğu Batı Yayınları. 